\title{
The nest, eggs, and nestling of Coopmans's Elaenia Elaenia brachyptera (Tyrannidae)
}

\author{
Harold F. Greeney ${ }^{1 *}$, Kimberly S. Sheldon ${ }^{1,2}$ \\ ${ }^{I}$ Yanayacu Biological Station \& Center for Creative Studies, $\mathrm{km} 5$, vía Las Caucheras, Cosanga, Napo, Ecuador. \\ ${ }^{2}$ Department of Ecology and Evolutionary Biology, 569 Dabney Hall, University of Tennessee, Knoxville, TN 37996, USA. \\ * Corresponding author, email: antpittanest@gmail.com \\ Editado por/Edited by: Esteban Guevara \\ Recibido/Received: 04/04/2018. Aceptado/Accepted: 07/10/2019. \\ Publicado en línea/Published online: 15/12/2019.
}

\begin{abstract}
Resumen
Proporcionamos las primeras descripciones del nido, huevos y pichón de la Elenia de Coopmans Elaenia brachyptera provenientes de las estribaciones del noreste de Ecuador. Describimos 7 nidos activos, 10 huevos y un polluelo de mediana edad. Los nidos son tazas abiertas, tejidas de fibras y raicillas pálidas y flexibles, decoradas externamente con varios materiales, organizados flojamente. Los nidos se ubicaron en pequeños retoños dentro de llanuras aluviales planas y rocosas. La colocación y la arquitectura del nido hacen que sea dificil diferenciarlos de materiales acumulados de forma natural por las inundaciones periódicas. El tamaño de puesta varió de 1-2 huevos y estimamos que el periodo de incubación duró 15-16 días. Los huevos son típicos del género, blanco-cremosos con pequeñas manchas canela y púrpura pálido (lavanda) concentradas en el extremo más grande. Proporcionamos también una revisión exhaustiva de la literatura publicada sobre los nidos, huevos o ecología reproductiva del género Elaenia, lo cual incluye estudios sobre 30 de los 46 taxones actualmente reconocidos.
\end{abstract}

Palabras clave: Biología reproductiva, estribaciones andinas, historia natural, Passeriformes.

\begin{abstract}
We provide the first descriptions of the nest, eggs, and nestling of Coopmans's Elaenia Elaenia brachyptera from the foothills of northeastern Ecuador. We describe 7 active nests, 10 eggs, and 1 mid-aged nestling. Nests are open cups, woven of flexible, pale fibers and rootlets, externally decorated with various loosely-arranged materials. They are placed in small saplings within flat, rocky, river floodplains. Nest placement and architecture make nests difficult to distinguish from naturally accumulated materials left behind by periodic flooding. Clutch size ranged from 1-2 eggs and we estimate incubation to last 15-16 days. Eggs are typical of the genus, buffy to creamy white with small cinnamon and lavender spots and blotches concentrated at the larger end. We also provide a comprehensive review of published literature on the nests, eggs, and breeding ecology for the genus Elaenia, including studies on 30 of the 46 currently recognized taxa.
\end{abstract}

Keywords: Andean foothills, breeding biology, natural history, Passeriformes.

\section{INTRODUCTION}

The genus Elaenia contains between 19 and 22 species (Lanyon, 1988; del Hoyo \& Collar, 2016; Remsen et $a l ., 2018$ ), encompassing up to 46 subspecies, that are distributed from Mexico and the Caribbean to the southern tip of South America (del Hoyo et al., 2018b). Compared to many groups of Neotropical flycatchers (Heming et al., 2013), the breeding biology of Elaenia is fairly well known, with descriptions of the nests and eggs available for 16 of the 19 species recognized by Banks et al. (1998) and Remsen et al. (2018). Coopmans's Elaenia Elaenia brachyptera, although described more than 100 years ago, has long been considered a subspecies of Lesser Elaenia E. chiriquensis (Cory \& Hellmayr, 1927; Hilty \& Brown, 1986; Ridgely \& Tudor, 2009). Previously known as Short-winged Elaenia (Cory \& Hellmayr, 1927), its new English name honors the late Paul Coopmans (Kirwan \& Freile, 2008; Krabbe, 2008). Differences in vocal (Ridgely \& Greenfield, 2001; Boesman, 2016), genetic (Rheindt et al., 2008, 2015), and plumage characters (Dickinson \& Christidis, 2014; del Hoyo \& Collar, 2016) support its elevation to species status. Coopmans's Elaenia occurs in the Andean 
foothills (700-2800 m elevation), favoring semi-open woodland, river edges, and clearings (del Hoyo et al., 2018a). Its known distribution range includes southwest Colombia to northwest Ecuador and, separately, the foothills and adjacent lowlands of eastern Ecuador (Rheindt et al., 2015). Along with Brownish Elaenia $E$. pelzelni and Great Elaenia E. dayi, Coopmans's Elaenia has no published breeding information (del Hoyo et al., 2018b). Here, we provide the first description of the nest, eggs, and nestling of this poorly studied species.

\section{METHODS}

From August 2006 to May 2007, during four visits made every 2-3 months, we encountered nests at two localities along the Baeza-Lago Agrio road in the province of Napo, northeastern Ecuador: Río Salado bridge $(-0.20555,-77.69055 ; 1290 \mathrm{~m})$ and Río Malo bridge $(-0.15388,-77.6425 ; 1270 \mathrm{~m})$. We measured nest dimensions to the nearest $0.1 \mathrm{~cm}$, supporting stem diameter to the nearest $0.1 \mathrm{~mm}$, and nest and substrate height to the nearest $0.1 \mathrm{~m}$. All means are given with $\pm \mathrm{SD}$.

\section{RESULTS}

\section{Nests}

We found seven active nests (Table 1) and an additional seven inactive nests that we suspect belonged to this species, based on their similarity in placement, form, and composition, and through elimination of other potential species building open cup nests in our study region, relying on the first author's experience with the nesting avifauna of this area. The nests (Figs. 1-2) were loosely woven open cups, composed predominantly of long, flexible pale fibers and rootlets. Although the nests lacked a well-differentiated internal lining, the fibers used for the interior of the cup tended to be slightly thinner and more tightly woven than material used for the exterior. Externally, the nests were lightly and loosely decorated with a wide variety of materials, including dead grasses, grass inflorescences, dead dicot leaves, small pieces of green moss, plastic string, spider egg sacs, and lepidopteran cocoons. Silk from these latter two items appeared to be used to help attach external decorations as well as to bind the nest together, especially along the rim and at points of attachment to the substrate. All nests were built in young saplings growing on flat, rocky, river islands or on similar floodplains adjacent to the river. The saplings used as substrates belonged to one of three genera: Tessaria $(\mathrm{n}=5$, Asteraceae), Baccharis ( $\mathrm{n}=5$, Asteraceae), Myrica $(\mathrm{n}=4$, Myricaceae). Along with Piper (Piperaceae), these were the most common saplings growing in the frequently-flooded areas where we encountered nests. Nests were built into upright forks of $2-6$ thin branches $(\mathrm{n}=14$ nests; mean $=3.7 \pm 1.1$ supports/nest), with branches measuring $0.5-17.1 \mathrm{~mm}$ in diameter $(\mathrm{n}=51$ supporting branches; mean diameter $=3.6 \pm 2.6 \mathrm{~mm})$. The nests were tightly attached to their substrate saplings by flexible fibers woven around the supporting stems as well as with small amounts of spider and lepidopteran silk. Nest height ranged from $0.5 \mathrm{~m}-1.7 \mathrm{~m}(\mathrm{n}=14$; mean $=1.1$ $\pm 0.4 \mathrm{~m})$, and substrate saplings were $0.7-2.5 \mathrm{~m}$ tall $(\mathrm{n}=14$; mean $=1.5 \pm 0.5 \mathrm{~m})$. Mean dimensions of the seven active nests were: $7.9 \pm 0.4 \mathrm{~cm}$ outer diameter; $6.2 \pm 0.4 \mathrm{~cm}$ outer height; $5.3 \pm 0.1 \mathrm{~cm}$ inner diameter; $4.1 \pm 0.4$ $\mathrm{cm}$ inner depth. Because of the composition, loose external attachment of material, and placement in riverside saplings, the nests of E. brachyptera had an overall appearance that was very similar to the many naturallyaccumulated clumps of detritus left behind after flooding (Fig. 2).

Table 1. Nests of Coopmans's Elaenia Elaenia brachyptera found in the province of Napo, northeastern Ecuador, August 2006 through May 2007.

\begin{tabular}{|c|c|c|c|}
\hline Date & Location & Contents & Comments \\
\hline 22 Oct & Río Salado & 1 developing egg & $\begin{array}{l}8 \text { Nov, } 1 \text { nestling, } 12.6 \mathrm{~g} \text {, primary pin } \\
\text { feathers ruptured } 0.5-2.5 \mathrm{~mm}\end{array}$ \\
\hline 22 Oct & Río Salado & 1 developing egg & \\
\hline 22 Oct & Río Salado & 2 developing eggs & 8 Nov, empty, cup slightly disturbed \\
\hline $8 \mathrm{Nov}$ & Río Salado & 2 developing eggs & \\
\hline $8 \mathrm{Nov}$ & Río Salado & 2 developing eggs & \\
\hline 9 Nov & Río Malo & 1 undeveloped egg & 23 Nov, 2 developed eggs, 1 pipped \\
\hline $20 \mathrm{Feb}$ & Río Salado & empty but complete, adult adding moss & \\
\hline
\end{tabular}




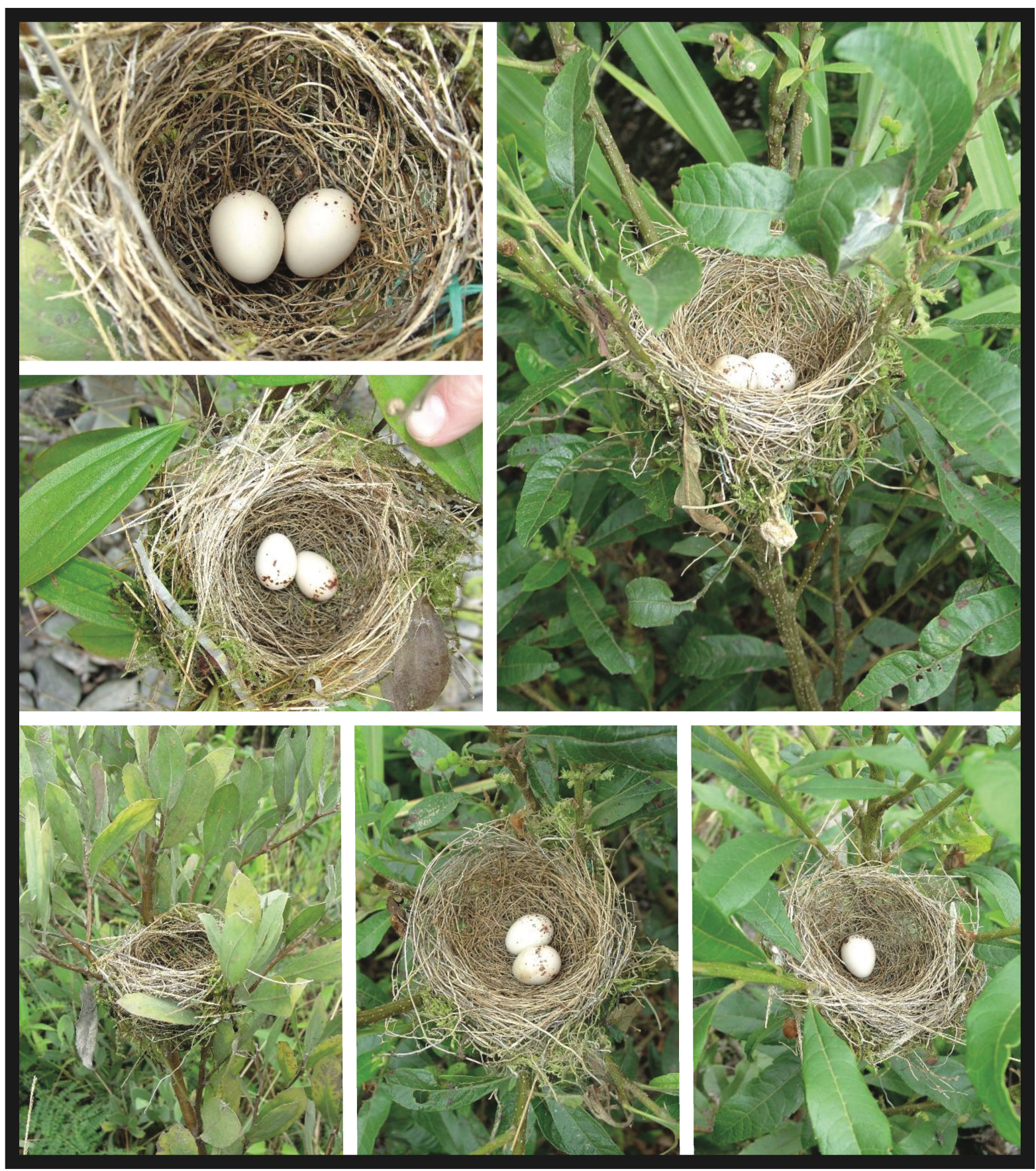

Figure 1: Nests of Coopmans’s Elaenia Elaenia brachyptera, province of Napo, Ecuador (H. F. Greeney).

\section{Eggs}

Of the six nests we observed during incubation, two contained one egg and four contained two eggs. Eggs were pale buff to off-white with cinnamon and lavender spotting and blotching, usually concentrated into an indistinct ring or cap at the larger end (Fig. 3). Ten eggs varied in length from 19.9-20.5 mm and in width from 14.6$15.1 \mathrm{~mm}$ (mean: $20.1 \pm 0.2 \times 14.9 \pm 0.2 \mathrm{~mm})$. One fresh egg weighed $2.29 \mathrm{~g}(20.0 \times 14.6 \mathrm{~mm})$, and one welldeveloped egg weighed $2.08 \mathrm{~g}(20.5 \times 14.9 \mathrm{~mm})$. One nest contained a single, undeveloped egg on 9 November (Table 1), that we marked with a permanent marker. Upon our return on 23 November, this egg was pipped, and would likely have hatched the following day. From this we estimate an incubation period of 15-16 days. 


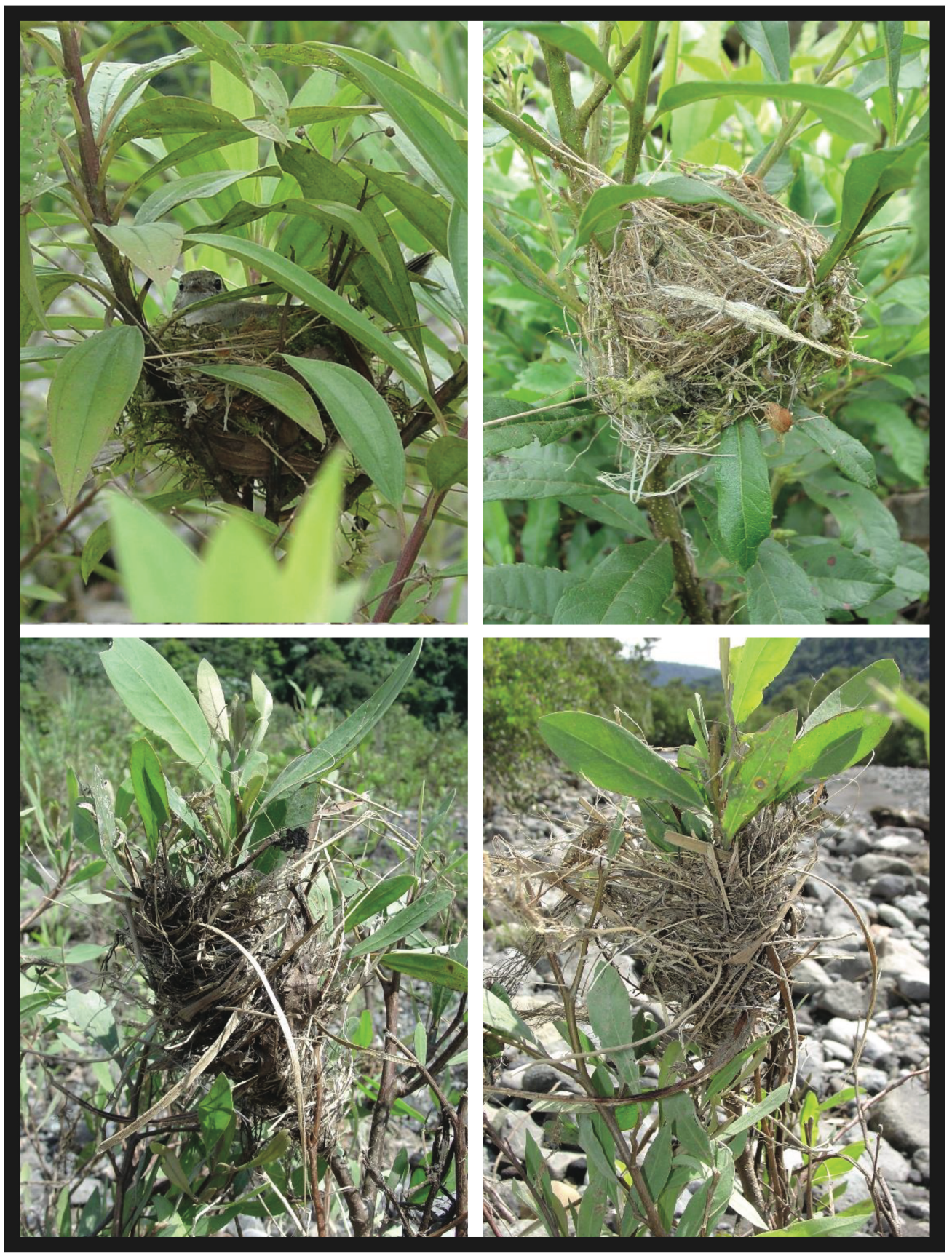

Figure 2: Nests of Coopmans's Elaenia Elaenia brachyptera, province of Napo, Ecuador (above). Naturally accumulated clumps of detritus that are scattered throughout the nesting habitat of Coopmans's Elaenia (below) (H. F. Greeney).

\section{Nestling}

We examined only a single, approximately half-grown nestling (Table 1, Fig. 4). Its eyes were fully opened, its primary feathers had emerged $0.5-2 \mathrm{~mm}$ from their sheaths, and contour feathers had ruptured their sheaths on all feather tracts. Feathers on the capital tract were the least developed, those on the crown and nape were just beginning to rupture from their sheaths, while those on the forecrown were unbroken. The tail feathers had emerged 1-3 mm from their sheaths. The emerging feathers of the greater and lesser wing coverts were whitish, but distinctly tinged with yellow. This suggests that immature birds can likely be distinguished from adults by their yellowish (rather than clean white) wing bars. The feathers of the upperparts were dull olive, becoming slightly warmer and browner towards the rump. The lower throat and upper breast feathers were dull olive, fading to yellow on the breast and then to white on the flanks and belly. Although difficult to tell at this age, we 
suggest that immature birds will differ from adults in having a darker and more extensive olivaceous wash to the upper breast. The maxilla was dull brownish, dull yellow along the tomia and at the base of the culmen, and still bore a small white egg tooth. The mandible was similar, but overall paler, washed with yellow. The rictal flanges were inflated and bright yellow, while the mouth lining was dull yellow, slightly tinged with orange.

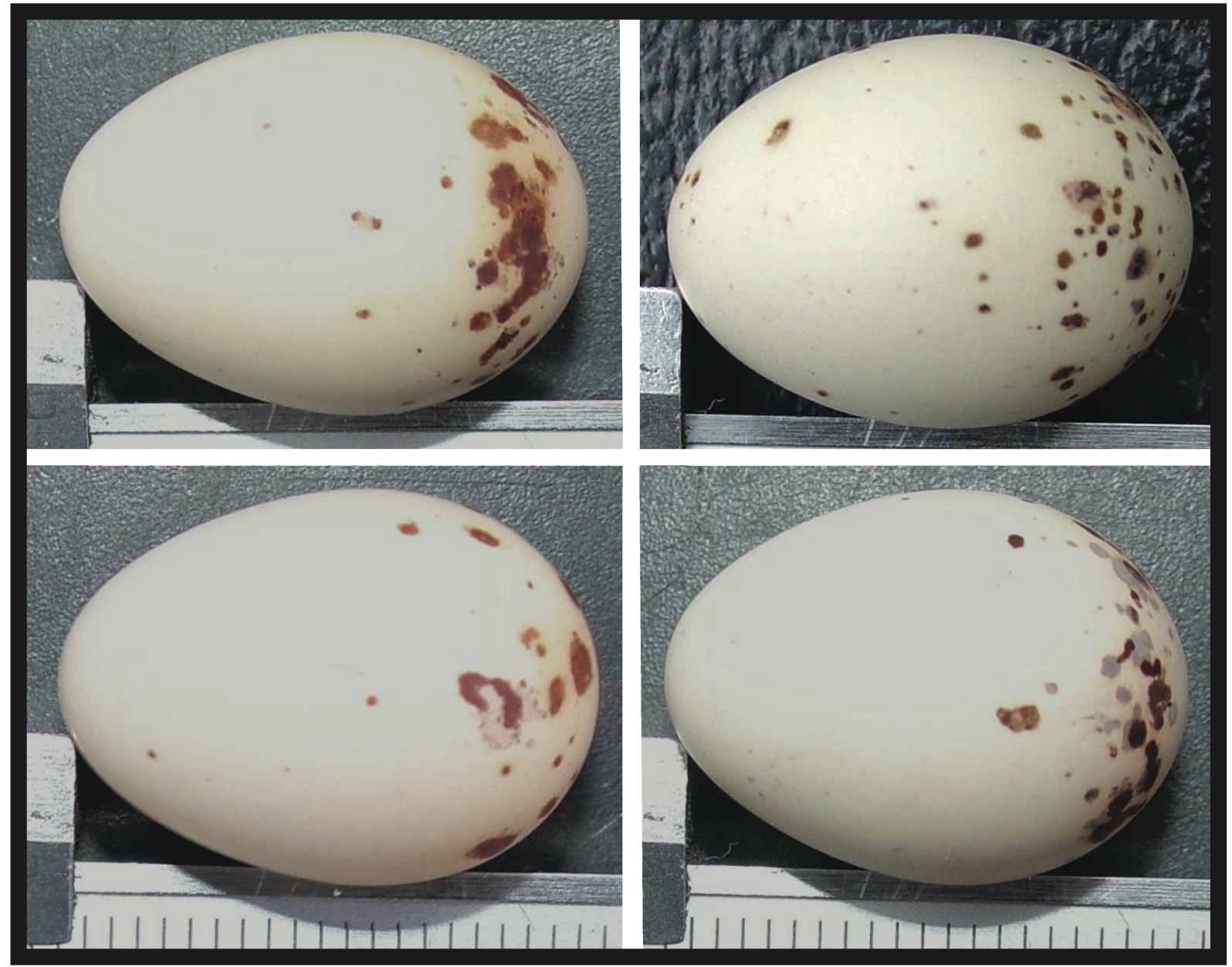

Figure 3: Eggs of Coopmans's Elaenia Elaenia brachyptera, province of Napo, Ecuador (H. F. Greeney).

\section{DISCUSSION}

Descriptions are now available for the nests, eggs, or breeding ecology of 17 of the 19 species, and 31 of the 46 currently recognized taxa of Elaenia (Banks et al., 1998; del Hoyo \& Collar, 2016; Remsen et al., 2018). The published literature includes data for the following taxa: Rufous-crowned Elaenia E. ruficeps (Tostain, 1988; Tostain et al., 1992); Plain-crested Elaenia E. cristata cristata (von Berlepsch \& Hartert, 1902; Cherrie, 1916; Haverschmidt, 1950; Hoffmann et al., 2009; Marini et al., 2009; Borges \& Marini, 2010; Lopes et al., 2013); Mottle-backed Elaenia E. gigas (Stawarczyk et al., 2009; Greeney et al., 2010); two subspecies of Highland Elaenia: E. obscura obscura (Hartert \& Venturi, 1909; Smyth, 1928; Narosky \& Salvador, 1998; de la Peña, 2001) and E. o. sordida (Nehrkorn, 1899; von Ihering, 1900; Lopes et al., 2013); Slaty Elaenia E. strepera (Hartert \& Venturi, 1909; Narosky \& Salvador, 1998; de la Peña, 1999; Auer et al., 2007); four subspecies of Yellow-bellied Elaenia: E. flavogaster flavogaster (Euler, 1867, 1900; Sclater \& Salvin, 1879; Wells, 1886; Nehrkorn, 1899; von Ihering, 1900; von Berlepsch \& Hartert, 1902; Hartert \& Venturi, 1909; Chubb, 1910; Cherrie, 1916; Bond, 1928; Smyth, 1928; Snethlage, 1935; Belcher \& Smooker, 1937; Hellebrekers, 1942; Miller, 1963; Snow \& Snow, 1964; Haverschmidt, 1968; Oniki, 1986; ffrench, 1991; Davis, 1993; de Andrade, 1996; Narosky \& Salvador, 1998; Chatellenaz \& Ferraro, 2000; Buzzetti \& Silva, 2008; Pereira \& Melo, 2009; Lopes et al., 2013; Hayes, 2014); E. f. subpagana (Cherrie, 1890; Carriker, 1910; Peck, 1910; Stone, 1918; Hallinan, 1924; Skutch, 1950, 1951, 1953; Amadon \& Eckleberry, 1955; Skutch, 1960, 1985; Howell \& Webb, 
1995; de Andrade, 1996); E. f. pallididorsalis (Stone, 1918; Wetmore, 1972; Ricklefs, 1976) and E. $f$. semipagana (Taczanowski, 1884); E. parvirostris (Barrows, 1883; von Berlepsch \& Hartert, 1902; Hartert \& Venturi, 1909; Cherrie, 1916; Serié \& Smyth, 1923; Smyth, 1928; de la Peña, 1987, 1999; Darrieu et al., 1988; Narosky \& Salvador, 1998; Buzzetti \& Silva, 2008; Hayes, 2014); Large Elaenia E. spectabilis (Schönwetter, 1967; de la Peña, 1987, 1995; Narosky \& Salvador, 1998; Chatellenaz \& Ferraro, 2000; di Giacomo, 2005; Hoffmann \& Krügel, 2007); Noronha Elaenia E. ridleyana (Oren, 1982); two subspecies of Lesser Elaenia: $E$. chiriquensis chiriquensis (Skutch, 1945, 1951; Blake, 1956; Skutch, 1960; Dickerman, 1971; Ricklefs, 1976, 1977) and E. c. albivertex (von Berlepsch \& Hartert, 1902; Belcher \& Smooker, 1937; Munves, 1975; ffrench, 1991; Narosky \& Salvador, 1998; Medeiros \& Marini, 2007; de Paiva, 2008; Pereira \& Melo, 2009; Borges \& Marini, 2010; Lopes et al., 2013); Coopmans's Elaenia E. brachyptera (this study); Olivaceous Elaenia $E$. mesoleuca (Nehrkorn, 1899; von Ihering, 1900; Hartert \& Venturi, 1909; Narosky \& Salvador, 1998; Hayes, 2014); Sierran Elaenia E. pallatangae intensa (Taczanowski, 1884; Londoño, 2014); three subspecies of Whitecrested Elaenia: E. albiceps albiceps (Allen, 1893; Schönwetter, 1979); E. a. chilensis (Oustalet, 1891; von Ihering, 1900; Oates \& Reid, 1903; Gibson, 1918; Smyth, 1928; Hellmayr, 1932; Reynolds, 1934; Johnson, 1965; Johnson \& Goodall, 1967; Schönwetter, 1979; de la Peña, 1987; Narosky \& Salvador, 1998; Ojeda \& Trejo, 2002; Willson et al., 2005; Mella \& Loutit, 2007); and E. a. modesta (Taczanowski, 1884; Nehrkorn, 1899); three subspecies of Mountain Elaenia: E. frantzii frantzii (Skutch, 1951; Blake, 1956; Skutch, 1967); $E$. f. pudica (Sclater \& Salvin, 1879; Oates \& Reid, 1903; Miller, 1963; Calderón-Leytón, 2002) and E.f. ultima (Howell \& Webb, 1995); five subspecies of Caribbean Elaenia: E. martinica martinica (Verrill, 1892; Oates \& Reid, 1903; Bond, 1941); E. m. caymanensis (Diamond, 1980); E. m. riisii (Schönwetter, 1979); E. m. barbadensis (Schönwetter, 1979) and E. m. remota (Howell \& Webb, 1995); and two subspecies of Greater Antillean Elaenia E. fallax fallax (Bond, 1943; Schönwetter, 1979) and E. f. cherriei (Bond, 1943).

With respect to basic nest form (open-cup), as well as egg form and coloration, information provided herein for E. brachyptera is clearly well-aligned with previous descriptions for the genus (see above). Similarly, a mean clutch size of 1.7 ( $\mathrm{n}=6$ clutches; Table 1$)$ follows general latitudinal trends towards reduced clutch size nearer the equator both within the genus Elaenia and for birds in general (Patten, 2007; Jetz et al., 2008). The resemblance of nests to flood-accumulated detritus has not been remarked upon for other species of Elaenia, and it is not known if the nesting of E. brachyptera is restricted to river floodplains. We encourage additional nest descriptions for this species, whose breeding remains unknown from other portions of its range (del Hoyo et al., 2018a). Testing the validity and effectiveness of this interesting form of mimetic nest crypsis will no doubt provide interesting insights into the species' natural history.

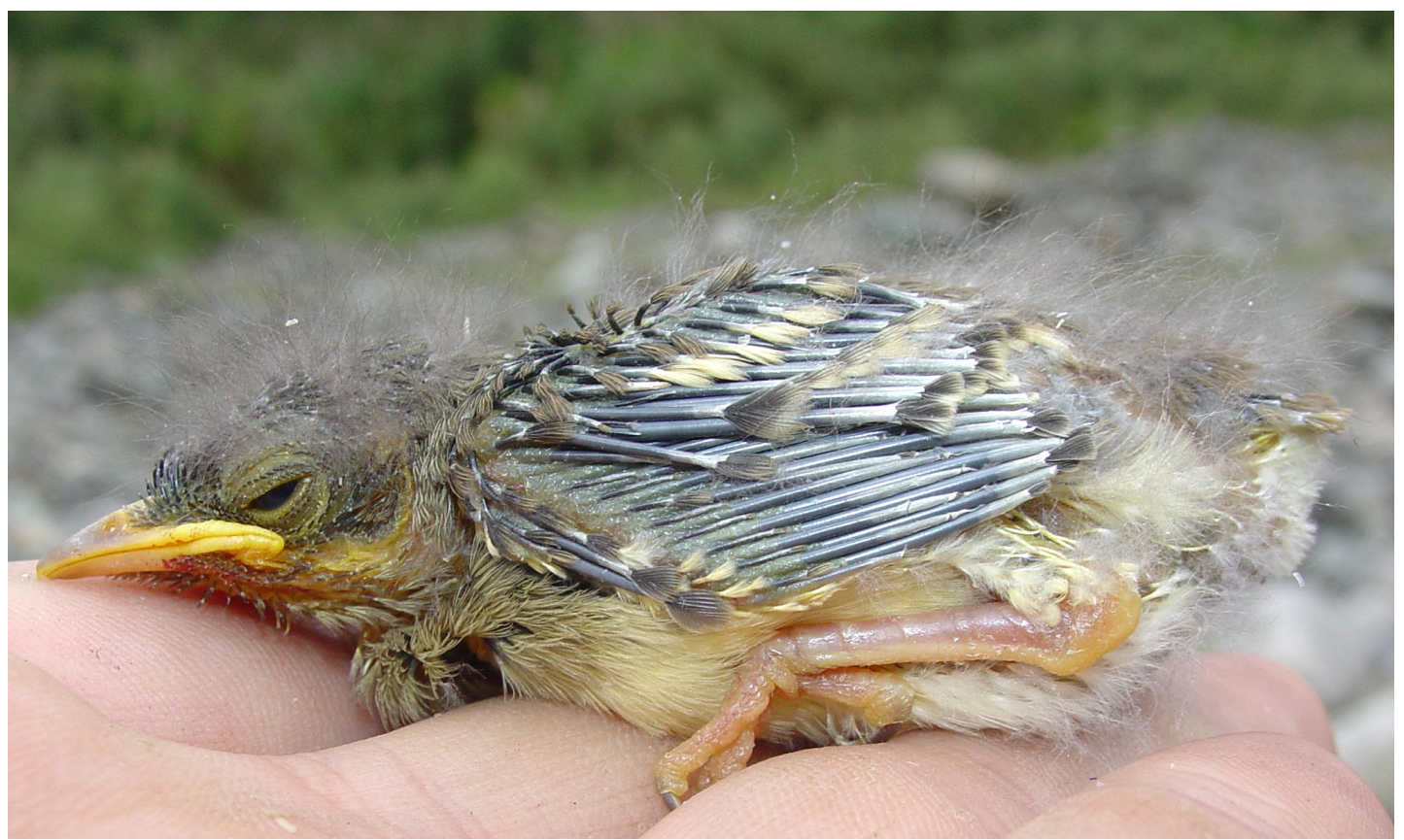

Figure 4: Mid-aged nestling of Coopmans's Elaenia Elaenia brachyptera, 8 November 2006, province of Napo, Ecuador (H. F. Greeney). 


\section{ACKNOWLEDGMENTS}

We thank José Simbaña and the staff of Yanayacu Biological Station for logistical support in the field. HFG thanks John V. and the late Ruth Ann Moore, Matt Kaplan, and Field Guides Inc. for their support through the Population Biology Foundation. HFG was supported during the writing of this manuscript by a fellowship from the John Simon Guggenheim Memorial Foundation. We thank two anonymous reviewers for their suggestions on earlier drafts. HFG is thankful for fond memories of exploring Ecuador with Paul Coopmans, and we dedicate this paper to Paul for his many contributions to Neotropical ornithology.

\section{REFERENCES}

Allen, J.A. (1893). On a collection of birds from Chapada, Matto Grosso, Brazil, by Mr. H. H. Smith. Part III. Pipridae to Rheidae. Bulletin of the American Museum of Natural History, 5, 107-158. URL: http://digitallibrary.amnh.org/handle/2246/1563

Amadon, D., \& Eckelberry, D.R. (1955). Observations on Mexican birds. Condor, 57(2), 65-80. DOI: https://doi.org/10.2307/1364549

de Andrade, M.A. (1996). Observações sobre ninhos e ovos de algumas aves em Minas Gerais. Atualidades Ornitológicas, $74,13-14$.

Auer, S.K., Bassar, R.D., Fontaine, J.J., \& Martin, T.E. (2007). Breeding biology of passerines in a subtropical montane forest in northwestern Argentina. Condor, 109(2), 321-333. DOI: https://doi.org/10.1650/00105422(2007)109[321:bbopia]2.0.c0;2

Banks, R.C., Fitzpatrick, J.W., Howell, T.R., Johnson, N.K., Monroe, B.L., Ouellet, H., Remsen, J.V., Jr., \& Storer, R.W. (1998). The species of birds of North America from the Arctic through Panama, including the West Indies and Hawaiian Islands (7th ed.). Lawrence, Kansas: American Ornithologists' Union \& Allen Press Inc.

Barrows, W.B. (1883). Birds of the lower Uruguay [part 3]. Bulletin of the Nuttall Ornithological Club, 8, $198-212$.

Belcher, C., \& Smooker, G.D. (1937). Birds of the colony of Trinidad and Tobago. Part V. Ibis, 79(2), 225-550. DOI: https://doi.org/10.1111/j.1474-919X.1937.tb02173.x

von Berlepsch, H.G., \& Hartert, E. (1902). On the birds of the Orinoco region. Novitates Zoologicae, 9, 1-134. URL: https://biodiversitylibrary.org/page/3268522

Blake, E.R. (1956). A collection of Panamanian nests and eggs. Condor, 58(5), 386-388. DOI: https://doi.org/10.2307/1365057

Boesman, P. (2016). Notes on the vocalizations of Lesser Elaenia (Elaenia chiriquensis): HBW Alive Ornithological Note 132. In J. del Hoyo, A. Elliott, J. Sargatal, D.A. Christie \& E. de Juana (Eds.), Handbook of the birds of the world alive. Barcelona, Spain: Lynx Edicions. http://www.hbw.com/node/932055

Bond, J. (1928). On the birds of Dominica, St. Lucia, St. Vincent, and Barbados, B.W.I. Proceedings of the National Academy of Science of Philadelphia, 80, 523-545. URL: https://www.jstor.org/stable/4064004

Bond, J. (1941). Nidification of the birds of Dominica, B. W. I. Auk, 58(3), 364-375. DOI: https://doi.org/10.2307/4078955

Bond, J. (1943). Nidification of the passerine birds of Hispaniola. Wilson Bulletin, 55(2), 115-125. URL: https://www.jstor.org/stable/4157234

Borges, F.J.A., \& Marini, M.Â. (2010). Birds nesting survival in disturbed and protected Neotropical savannas. Biodiversity and Conservation, 19(1), 223-236. URL: https://ink.springer.com/article/10.1007/s10531-009-9718-Z

Buzzetti, D.R.C., \& Silva, S. (2008). Berços da vida, ninhos de aves brasileiras. São Paulo, Brasil: Editora Terceiro Nome. 
Calderón-Leytón, J.J. (2002). Aves de la laguna de la Cocha. San Juan de Pasto, Colombia: Asociación para el Desarrollo Campesino ADC.

Carriker, M.A., Jr. (1910). An annotated list of the birds of Costa Rica, including Cocos Island. Annals of the Carnegie Museum, 6(7), 314-915. URL: https://mczbase.mcz.harvard.edu/media/295751

Chatellenaz, M.L., \& Ferraro, L.I. (2000). Materiales vegetales y fúngicos utilizados por aves en la construcción de nidos en el noreste argentino y Paraguay. Comunicaciones Cientificas y Tecnológicas, Universidad Nacional del Nordeste, Corrientes, Argentina, 1, 1-4.

Cherrie, G.K. (1890). Notes on the nesting habits of several birds at San José, Costa Rica. Auk, 7(3), 233-237. DOI: https://doi.org/10.2307/4067981

Cherrie, G.K. (1916). A contribution to the ornithology of the Orinoco region. Science Bulletin of the Museum of the Brooklyn Institute of Arts and Sciences, 2, 133-374. DOI: https://doi.org/10.5962/bhl.title.20610

Chubb, C. (1910). On the birds of Paraguay. Part IV. Ibis, 52(4), 571-647. DOI: https://doi.org/10.1111/j.1474919X.1910.tb07922.x

Cory, C.B., \& Hellmayr, C.E. (1927). Catalogue of birds of the Americas and the adjacent islands. Part V. Tyrannidae. Field Museum of Natural History (Zoological Series), 13(5), 1-523. URL: https://www.biodiversitylibrary.org/part/78623

Darrieu, C.A., Soave, G., \& Soave, E. (1988). Nidificación de Passeriformes en la Reserva Integral de Punta Lara y sus alrededores. Hornero, 13, 53-58.

Davis, S.E. (1993). Seasonal status, relative abundance, and behavior of the birds of Concepción, Dept. Santa Cruz, Bolivia. Feldiana Zoology, 71, 1-33. DOI: https://doi.org/10.5962/bhl.title.3409

Diamond, A.W. (1980). Ecology and species turnover of the birds of Little Cayman. Atoll Research Bulletin, 241, 141164.

Dickerman, R.W. (1971). Further notes on Costa Rica birds. Condor, 73(2), 252-253. DOI: https://doi.org/10.2307/1365850

Dickinson, E.C., \& Christidis, L. (2014). The Howard and Moore complete checklist of the birds of the world. 4th Edition. Volume 2, Passerines. Eastbourne, UK: Aves Press.

Di Giacomo, A.G. (2005). Aves de la Reserva El Bagual. In A.G. Di Giacomo \& S. Krapovickas (Eds.), Historia natural y paisaje de la Reserva El Bagual, provincia de Formosa, Argentina. Inventario de la fauna de vertebrados y de la flora vascular de un área protegida del Chaco Húmedo (pp. 201-465). Buenos Aires, Argentina: Aves Argentinas/AOP.

Euler, C. (1867). Beiträge zur Naturgeschichte der Vögel Brasiliens, II. Journal für Ornithologie, 15(4), $217-233$.

Euler, C. (1900). Descripção de ninhos e ovos das aves do Brazil. Revista do Museu Paulista 4, 9-148.

ffrench, R. (1991). Birds of Trinidad and Tobago. Ithaca, New York: Cornell University Press.

Gibson, E. (1918). Further ornithological notes from the neighbourhood of Cape San Antonio, Province of Buenos Ayres. Part I. Passeres. Ibis, 60(3), 363-415. DOI: https://doi.org/10.1111/j.1474-919X.1918.tb00790.x

Greeney, H.F., Juiña-J., M.E., Harris, J.B.C., Wickens, M.T., Winger, B., Gelis, R.A., Miller, E.T. \& Solano-Ugalde, A. (2010). Observations on the breeding biology of birds in south-east Ecuador. Bulletin of the British Ornithologists' Club, 130(1), 61-68. URL: https://biodiversitylibrary.org/page/47499620

Hallinan, T. (1924). Notes on some Panama Canal Zone birds with special reference to their food. Auk, 41(2), 304-326. DOI: https://doi.org/10.2307/407462

Hartert, E., \& Venturi, S. (1909). Notes sur les oiseaux de la Republique Argentine. Novitates Zoologicae, $16(2), 159-267$. DOI: https://doi.org/10.5962/bhl.part.21963 
Haverschmidt, F. (1950). Bird records from Surinam, Dutch Guiana. Auk, 67(2), 217-221. DOI: https://doi.org/10.2307/4081215

Haverschmidt, F. (1968). Birds of Surinam. London, UK: Oliver and Boyd.

Hayes, F.E. (2014). Breeding season and clutch size of birds at Sapucái, Departamento Paraguarí, Paraguay. Boletín del Museo Nacional de Historia Natural del Paraguay, 18(1), 77-97. URL: www.faunaparaguay.com/Bol18hayes.pdf

Hellebrekers, W.P.J. (1942). Revision of the Penard oölogical collection from Surinam. Zoologische Mededeelingen, 24, 240-275.

Hellmayr, C.E. (1932). The birds of Chile. Field Museum of Natural History (Zoological Series), 20(308), 1-472. URL: https://www.biodiversitylibrary.org/item/20866

Heming, N.M., Greeney, H.F., \& Marini, M.Â. (2013). Breeding biology research and information availability for New World birds. Natureza \& Conservação, 11(1), 54-58.

Hilty, S.L., \& Brown, W.L. (1986). A guide to the birds of Colombia. Princeton, NJ: Princeton University Press.

Hoffmann, D., \& Krügel, M. M. (2007). Biologia reprodutiva de Elaenia spectabilis Pelzeln, 1868 (Aves, Tyrannidae) no município de Santa Maria, Rio Grande do Sul, Brasil. Revista Brasileira de Ornitologia 15(3), 453-456. URL: www4.museu-goeldi.br/revistabrornito/revista/index.php/BJO/article/download/3018/pdf_509

Hoffmann, D., Gomes, H.B., \& Guerra, T. (2009). Biologia reprodutiva de Elaenia cristata Pelzeln, 1868 (Passeriformes: Tyrannidae) em duas áreas de campos rupestres de Minas Gerais, Brasil. Revista Brasileira de Ornitologia, 17(2), 102106. URL: www4.museu-goeldi.br/revistabrornito/revista/index.php/BJO/article/download/3604/pdf_791

Howell, S.N.G., \& Webb, S. (1995). A guide to the birds of Mexico and northern Central America. Oxford, U.K.: Oxford University Press.

del Hoyo, J. \& Collar, N.J. (2016). HBW and BirdLife International illustrated checklist of birds of the world, vol. 2: Passerines. Barcelona, Spain: Lynx Edicions.

del Hoyo, J., Collar, N.J., \& Kirwan, G.M. (2018a, 1 April). Coopmans's Elaenia (Elaenia brachyptera). In J. del Hoyo, A. Elliott, J. Sargatal, D.A. Christie, \& E. de Juana. (Eds.), Handbook of the birds of the world alive. Barcelona, Spain: Lynx Edicions. https://www.hbw.com/node/1343700

del Hoyo, J., Elliott, A., Sargatal, J., Christie, D.A., \& de Juana, E. (eds.) (2018b, 1 April). Handbook of the birds of the world alive. Barcelona, Spain: Lynx Edicions. https://www.hbw.com

Von Ihering, H. (1900). Catálogo crítico-comparativo dos ninhos e ovos das aves do Brazil. Revista do Museu Paulista, 4 , 191-300.

Jetz, W., Sekerçioglu, C.H., \& Böhning-Gaese, K. (2008). The worldwide variation in avian clutch size across species and space. PLoS Biology, 6(12), 2650-2657. DOI: 10.1371/journal.pbio.0060303

Johnson, A.W. (1965). The birds of Chile. Buenos Aires, Argentina: Published privately.

Johnson, A.W., \& Goodall, J.D. (1967). The birds of Chile and adjacent regions of Argentina, Bolivia, and Peru. Buenos Aires, Argentina: Platt Establecimientos Gráficos, S.A.

Kirwan, G.M., \& Freile, J.F. (2008). Current perspectives in Ecuadorian ornithology and conservation: A tribute to Paul Coopmans. Cotinga, 29, 2-3.

Krabbe, N. (2008). Birding Ecuador: A tribute to Paul Coopmans. Cotinga, 29, 12-14.

Lanyon, W.E. (1988). A phylogeny of the thirty-two genera in the Elaenia assemblage of tyrant flycatchers. American Museum Novitates, 2914, 1-57. URL: http://hdl.handle.net/2246/5173

Londoño, G.A. (2014). Anidación de aves en un gradiente altitudinal: Rapid Color Guide \# 514, versión 1. Chicago, Illinois. The Field Museum. URL: https:/fieldguides.fieldmuseum.org/es/guías/guía/514 
Lopes, L.E., Peixoto, H.J.C., \& Hoffmann, D. (2013). Notas sobre a biologia reprodutiva de aves brasileiras. Atualidades Ornitológicas, 171, 33-49.

Marini, M.Â., Sousa, N.O.D.M., Borges, F.J.A., \& Silviera, M.B. (2009). Biologia reproductiva de Elaenia cristata (Aves: Tyrannidae) em cerrado do Brasil Central. Neotropical Biology and Conservation, 4, 3-12.

Medeiros, R.C.S., \& Marini, M.Â. (2007). Biologia reprodutiva de Elaenia chiriquensis (Lawrence) (Aves, Tyrannidae) em Cerrado do Brasil Central. Revista Brasileira de Zoologia, 24(1), 12-20. DOI: http://dx.doi.org/10.1590/S0101$\underline{81752007000100002}$

Mella, J.E., \& Loutit, A. (2007). Ecología comunitaria y reproductiva de aves en cerros, islas y parques de Santiago. Boletín Chileno de Ornitología, 13, 13-27.

Miller, A.H. (1963). Seasonal activity and ecology of the avifauna of an American equatorial cloud forest. University of California Publications in Zoology, 66, 1-78.

Munves, J. (1975). Birds of a highland clearing in Cundinamarca, Colombia. Auk, 92(2), 307-321. DOI: https://doi.org/10.2307/4084559

Narosky, T., \& Salvador, S. (1998). Nidificación de las aves argentinas, Tyrannidae. Buenos Aires, Argentina: Asociación Ornitológica del Plata.

Nehrkorn, A. (1899). Katalog der Eiersammlung nebst Beschreibungen der Aussereuropäschen Eier. Braunschweig, Germany: Harald Bruhn. URL: http://www.biodiversitylibrary.org/bibliography/13722

Oates, E.W., \& Reid, S.G. (1903). Catalogue of the collection of birds' eggs in the British Museum (Natural History). Volume 3: Carinatae (Psittaciformes-Passeriformes). London, U.K.: British Museum of Natural History.

Ojeda, V., \& Trejo, A. (2002). Primeros registros de nidificación en cavidades para tres especies de aves del bosque andino patagónico. Hornero, 17(2), 85-89.

Oniki, Y. (1986). Nidificação de aves em duas localidades amazônicas: sucesso e adaptações. (PhD Dissertation). Universidade Estadual de Campinas, Campinas, Brasil.

Oren, D.C. (1982). A avifauna do arquipélago de Fernando de Noronha. Boletim do Museu Paraense Emílio Goeldi, série Zoologia, 118, 1-22.

Oustalet, E. (1891). Oiseaux. In Mission scientifique du cap Horn, 1882-1883 (pp. 1-341). Paris, France: Gauthier-Villars et fils, Imprimeurs-Libraires.

de Paiva, L.V. (2008). Fatores que determinam o periodo reproductivo de Elaenia chiriquensis (Aves: Tyrannidae) no cerrado do Brasil central. (PhD Dissertation). Universidade de Brasília, Brasília, Brasil.

Patten, M.A. (2007). Geographic variation in calcium and clutch size. Journal of Avian Biology, 38(6), 637-643. DOI: https://doi.org/10.2307/30245187

Peck, M.E. (1910). The effect of natural enemies on the nesting habits of some British Honduras birds. Condor, 12(2), 5360. DOI: https://doi.org/10.2307/1362090

de La Peña, M.R. (1987). Nidos y huevos de aves argentinas. Santa Fe, Argentina: Published by the author.

de La Peña, M.R. (1995). Ciclo reproductivo de aves argentinas. Santa Fe, Argentina: Centro de Publicaciones, Universidad Nacional del Litoral.

de La Peña, M.R. (1999). Nidos y huevos de aves argentinas, guía de campo. Santa Fe, Argentina: Fundación Hábitat y Desarrollo.

de La Peña, M.R. (2001). Nidificacion de algunas especies de aves en el este de la provincia de Catamarca, Argentina. Hornero, 16, 17-21. 
Pereira, Z.D.P., \& Melo, C. (2009). Diversidade de aves e reprodução de Passeriformes em áreas de Cerrado sensu stricto e veredad. In IX Encontro Interno \& XIII Seminario de Iniciação Científica. Uberlândia, Brazil: Universidade Federal de Uberlândia.

Remsen, J.V., Jr., Areta, J.I., Cadena, C.D., Claramunt, A., Jaramillo, A., Pacheco, J.F., Pérez-Emán, J., Robbins, M.B., Stiles, F.G., Stotz, D.F., \& Zimmer, K.J. (2018, 30 March). A classification of the bird species of South America. Washington, DC: American Ornithologists' Union. http://www.museum.lsu.edu/ Remsen/SACCBaseline.html

Reynolds, P.W. (1934). Apuntes sobre aves de Tierra del Fuego. Hornero, 5, 339-353.

Rheindt, F.E., Christidis, L., \& Norman, J.A. (2008). Habitat shifts in the evolutionary history of a Neotropical flycatcher lineage from forest and open landscapes. BMC Evolutionary Biology, 8, art. 193. URL: http://www.biomedcentral.com/1471-2148/8/193

Rheindt, F.E., Krabbe, N., Wee, A.K.S., \& Christidis, L. (2015). Cryptic speciation in the Lesser Elaenia Elaenia chiriquensis (Aves: Passeriformes: Tyrannidae). Zootaxa, 4032(3), 251-263. DOI:

http://dx.doi.org/10.11646/zootaxa.4032.3.1

Ricklefs, R.E. (1976). Growth rates of birds in the humid New World tropics. Ibis, 118(2), 179-207. DOI: https://doi.org/10.1111/j.1474-919X.1976.tb03065.x

Ricklefs, R.E. (1977). Reactions of some Panamanian birds to human intrusion at the nest. Condor, 79(3), 376-379. https://doi.org/10.2307/1368016

Ridgely, R.S., \& Greenfield, P.J. (2001). Birds of Ecuador. Volume 1: status, distribution, and taxonomy. Ithaca, NY: Cornell University Press.

Ridgely, R.S., \& Tudor, G. (2009). Field guide to the songbirds of South America: the passerines. Austin, TX: University of Texas Press.

Schönwetter, M. (1967). Handbuch der Oölogie (vol. 1). Berlin, Germany: Akademie-Verlag.

Schönwetter, M. (1979). Handbuch der Oölogie (vol. 2). Berlin, Germany: Akademie-Verlag.

Sclater, P.L., \& Salvin, O. (1879). On the birds collected by the late Mr. T. K. Salmon in the State of Antioquia, United States of Colombia. Proceedings of the Zoological Society of London, 47(1), 486-550. DOI: https://doi.org/10.1111/j.10963642.1879.tb02684.x

Serié, P., \& Smyth, C.H. (1923). Notas sobre aves de Santa Elena (E. Ríos). Hornero, 3, 37-55.

Skutch, A.F. (1945). Incubation and nestling periods of Central American birds. Auk, 62(1), 8-37. DOI: https://doi.org/10.2307/4079958

Skutch, A.F. (1950). The nesting seasons of Central American birds in relation to climate and food supply. Ibis, 92(2), 185-222. DOI: https://doi.org/10.1111/j.1474-919X.1950.tb01749.x

Skutch, A.F. (1951). Congeneric species of birds nesting together in Central America. Condor, 53(1), 3-15. DOI: https://doi.org/10.2307/1364581

Skutch, A.F. (1953). How the male bird discovers the nestlings (cont.). Ibis, 95(3), 505-542. DOI: https://doi.org/10.1111/j.1474-919X.1953.tb00711.x

Skutch, A.F. (1960). Life histories of Central American birds II. Pacific Coast Avifauna, 34, 1-593. URL: https://sora.unm.edu/sites/default/files/journals/pca/pca_034.pdf

Skutch, A.F. (1967). Life histories of Central American birds III. Cambridge, MS: Nuttall Ornithological Club. URL: https://sora.unm.edu/sites/default/files/journals/pca/pca_035.pdf

Skutch, A.F. (1985). Clutch size, nesting success, and predation on nests of Neotropical birds, reviewed. Ornithological Monographs, 36, 575-594. 
Smyth, C.H. (1928). Descripción de una colección de huevos de aves argentinas. Hornero, 4(2), 125-152. URL: http://digital.bl.fcen.uba.ar/Download/008 ElHornero/008 ElHornero v004 n02 articulo125.pdf

Snethlage, E. (1935). Beiträge zur Fortpflanzungsbiologie brasilianischer Vögel. Journal für Ornithologie, 83, 532-562.

Snow, D.W., \& Snow, B.K. (1964). Breeding seasons and annual cycles of Trinidad land-birds. Zoologica, 49, 1-39.

Stawarczyk, T., Greeney, H.F., \& Simbaña, J. (2009). First description of a nest of the Mottle-backed Elaenia Elaenia gigas. Cotinga, 31, 134-135.

Stone, W. (1918). Birds of the Panama Canal Zone with special reference to a collection made by Lindsey L. Jewel. Proceedings of the Academy of Natural Sciences of Philadelphia, 70, 239-280.

Taczanowski, L. (1879). Liste des oiseaux recueillis au Nord de Pérou occidental par M. Stolzmann en 1878. Proceedings of the Zoological Society of London, 47(1), 220-245.

Taczanowski, L. (1884). Ornithologie du Pérou, Volume 2. Berlin, Germany: R. Friedländer \& Sohn. URL: https://www.archive.org/download/ornithologiedup02tacz/ornithologiedup02tacz.pdf

Tostain, O. (1988). Découverte du nid de l'Elaène tête-de-feu (Elaenia ruficeps), Tyrannidae, en Guyane française. Alauda, $56,174-175$.

Tostain, O., Dujardin, J.-L., Érard, C.H., \& Thiollay, J.M. (1992). Oiseaux de Guyane. Brunoy, France: Société d'Etudes Ornithologiques.

Verrill, G.E. (1892). Notes on the fauna of the Island of Dominica, British West Indies, with lists of the species obtained and observed by G. E. and A. H. Verrill. Transactions of the Connecticut Academy of Arts and Sciences, 8, 315-355.

Wells, J.G. (1886). A catalogue of the birds of Grenada, West Indies. Proceedings of the United States National Museum, 9, 609-661.

Wetmore, A. (1972). Birds of the Republic of Panama. Part III. Dendrocolaptidae (Woodcreepers) to Oxyruncidae (Sharpbills). Washington, DC: Smithsonian Institution Press.

Willson, M.F., De Santo, T.L., Sieviing, K.E., \& Armesto, J.J. (2005). Nest success of open-cup nesting birds in Chilean rainforest. Boletín Chileno de Ornitología, 11, 11-17. 